\title{
Latest Cretaceous leaf floras from southern Poland and western Ukraine
}

Adam T. Halamski

Acta Palaeontologica Polonica 58 (2), 2013: 407-443 doi: http://dx.doi.org/10.4202/app.2011.0024

Latest Cretaceous (Campanian to Maastrichtian) leaf floras are described from 33 outcrops ranging from the southern border of the Holy Cross Mountains (southern Poland) through the Roztocze region (south-eastern Poland) to the vicinity of L'viv (western Ukraine). The flora is allochthonous, preserved in marine sediments, yet complete compound leaves strongly argue for the transport having been short. Krasnobród and Potelych (Potylicz) are the richest localities; both are late Campanian. The abundance of angiosperm remains in this period is explained by a marine lowstand resulting in nearby emergent vegetated areas. The flora is composed of ferns (three species), conifers (five species, including the commonest Geinitzia reichenbachii), dicotyledons (seventeen taxa; Debeya paulinae sp. nov., two other species of Debeya, and Rarytkinia polonica being the most frequent), and a single presumed monocotyledon. The eudicot clade is formalised as supersubclass Eudicotyledoneae Doyle and Hotton ex Halamski, herein. The approximately equal abundance of serrate/lobate and entire-margined dicots attests to an intermediate character of the flora between more thermophilic and polar vegetation. The studied material may have come from at least two communities: xeromorphic mixed Debeya-conifer forests and platanoid-Lauraceae forests growing in disturbed environments along rivers. The studied assemblage is most similar to approximately coeval floras from Westphalia and the Netherlands.

Key words: Angiospermae, Coniferae, Leptosporangiatae, Debeya, palaeobotany, taxonomy, Campanian, Maastrichtian, Cretaceous, Poland, Ukraine.

Adam T. Halamski [ath@twarda.pan.pl], Institute of Paleobiology, Polish Academy of Sciences, Twarda 51/55, 00-818 Warszawa, Poland.

This is an open-access article distributed under the terms of the Creative Commons Attribution License (for details please see creativecommons.org), which permits unrestricted use, distribution, and reproduction in any medium, provided the original author and source are credited. 
FoF Full text $(3,380.0 \mathrm{kB})$ 